\title{
Marc-Antoine Muret and his Lectures on Cicero's De officiis
}

This chapter focuses on Cicero's De officiis, his spiritual legacy written in the last months of $44 \mathrm{BCE}^{1}$ and on a pivotal figure of the European Renaissance, MarcAntoine Muret.

I will investigate how Muret makes use of De officiis in his academic work at University of Rome 'La Sapienza'2 and the role the treatise could have played in Rome at the time of the Counter-Reformation. Cicero wrote it during the fall of the Roman Republic, at the very end of his life, in order to hand the Roman value system down to young people. For this reason, Muret considered De officiis an inspirational work for the students in his class on eloquence. The cornerstone of his reading of the work is that moral philosophy is indispensable for eloquence to function as a political tool, as it did in Cicero's time.

\section{Marc-Antoine Muret}

Muret was an extraordinary figure ${ }^{3}$ who lived between 1526 and 1585 and who was active mainly in France, then in Italy, in Venice and Rome. He was a poet, orator and professor; his work as a philologist includes numerous editions of and scholia on works by Cicero, Horace, Seneca, Juvenal and Tacitus. Muret was also a key element in the complex landscape of humanism: he gave a new interpretation to secular culture after the Council of Trent ${ }^{4}$ and played a fundamental role in the debate around Cicero and the Tullianus stylus in the posttridentine age.

1 For De officiis as Cicero’s ‘spiritual legacy’, cf. Gabba 1979, 119: “Cicerone vuole riconfermare i fondamenti culturali e ideologici dello stato romano [...] le basi ideali (ma anche idealizzate) della vita politica romana; i modi di comportamento politico che avrebbero dovuto essere connaturati con la vita politica stessa".

2 For a sketch of the environment at 'La Sapienza' during the years of Counter-Reformation, cf. Loverci 2000, 199-243; Conte 1993; Renazzi 1803-1806, 197-203.

3 On Muret, cf. Kraye 2005, 307-330; IJsewijn 1998; Mouchel 1997; Renzi 1993; Sharratt 1991; Ginsberg 1988, 63-69; Fumaroli 1980, 162-175; Dejob 1881.

4 The Council of Trent, which began in 1545 and ended in 1563 after many interruptions, was one of the most important Councils of the Catholic Church, convoked in reaction to the Protestant Reformation.

Ә OpenAccess. () 2020 Barbara Del Giovane, published by De Gruyter. (cc))BY-NC-ND This work is licensed under the Creative Commons Attribution-NonCommercial-NoDerivatives 4.0 License. 
According to Croll, who offered pioneering contributions concerning Muret's prose, ${ }^{5}$ Muret was the initiator of the so-called 'anti-Ciceronian' movement, which lasted until the seventeenth century. Croll identifies the starting point of this movement in the speech given by Muret in 1572 at the beginning of the academic year: ${ }^{6}$ in this speech Muret harshly criticizes slavish imitators of Cicero's style, whom he calls magpies and parrots. However, Croll's position on Muret as an anti-Ciceronian has been called into question ${ }^{7}$ since Muret, whom Josephus Justus Scaliger considered the best speaker and writer of Latin after Cicero, ${ }^{8}$ rejects not Cicero's prose per se but the use of Cicero's prose to convey something which is not a "true and authentic" text of one's own. ${ }^{9}$ The most obvious target of this polemic is Mario Nizzoli, mentioned in the oration of 1572 . He edited a Latin dictionary containing only Ciceronian words, the Thesaurus Ciceronianus, to which Muret is clearly alluding in his critique of those who write using words and constructions that only "smell like Cicero". ${ }^{10}$

In the milieu of the Counter-Reformation, the role of Cicero and of pagan prose had to be re-thought and Muret, by advocating "une réforme prudente de la tradition cicéronianiste", ${ }^{11}$ was the first to understand how the Tullianus stylus could be adapted to the need for renewal of the Clergy. Muret stands out thanks to his lucidity in analysing both the cultural and the political environment of his era. He describes it as a time of barbarians, ${ }^{12}$ and then reflects on how forensic oratory has died, making way for epideictic oratory and letter writing. Muret draws a comparison with the shift from Cicero's time to that of the Principate, during which frankness had to be replaced by wise prudence. ${ }^{13}$ Therefore, even if "Cicero's connection of oratory with liberty" ${ }^{14}$ remains the con-

5 The most significant is Croll 1966.

6 De uia et ratione ad eloquentiae laudem perueniendi [henceforth De uia et ratione], Oratio XXI.

7 Fumaroli 1980, 162-175 and passim; Mouchel 1997; IJsewijn 1998: Kraye 2005, 310.

8 Scaliger, Scaligerana 465-466 Desmaizeaux: Muret [...] s'est moqué des Ciceroniens, \& cependant parle fort Ciceroniennement [...] Mureto nullus fuit post Ciceronem qui expeditius loqueretur et scriberet Romane.

9 Muret, De uia et ratione 262: Picarum et psittacorum ista eloquentia est, auditas uoces iterare ac reddere neque quidquam unquam dicere quod sit uere ac proprie tuum. The texts of the orations by Muret are taken from Frotscher's 1834-1841 Leipizig edition.

10 Muret, De uia et ratione 261: Hodie enim ut quis uulgaria Rhetorum praecepta utcunque didicit et in Ciceronis scriptis tantum posuit operae, ut, adhibito Nizolii libro, possit orationem aut epistolam scribere, cuius tum singulas uoces tum ipsa etiam structura et collocatio Ciceronem oleat, protinus magno eorum consensu qui nihil altius aut sublimius cogitant, eloquentis nomen assumit.

11 Fumaroli 1980, 164.

12 Cf. e.g. Muret, Oratio XVI 402.

13 McGinness 1995a, 12.

14 Vickers 1989, 36. 
ceptual premise in approaching the topic of eloquence, the model of Tacitus becomes increasingly relevant. ${ }^{15}$ In fact, Muret's portrayal of "people who saved their lives by avoiding an unseasonable frankness" ${ }^{16}$ recalls the example of Agricola, capable of appeasing Domitian due to his prudence and moderation, and his lack of empty arrogance. ${ }^{17}$

\section{The praelectio on De officiis}

During his tenure as Professor of Rhetoric, in 1574, Muret taught a class on Cicero's De officiis. University classes were generally inaugurated with a praelectio, a speech in which the topic of the class was elucidated, and which has also been interpreted as a form of "transmission of knowledge"18 stemming from the Middle Ages ${ }^{19}$ and renewed in the Renaissance. We have the text of the praelectio on De officiis, held in November 1574: Oratio VI, Ingressurus explanare M. T. Ciceronis libros De officiis. ${ }^{20}$ We do not possess the written texts of Muret's lectures but, in the case of his lectures on De officiis, the publication of the scholia on this work gives us some hints on Muret's reading and commentary. ${ }^{21}$

In Claire's analysis of the structure of Muret's orationes ${ }^{22}$ two elements are seen as indispensable: the praise (laus) of the work which will be taught and the exhortation to the students to engage with this work (cohortatio). As we will see, Oratio VI only partially fits into this scheme. Nevertheless, it represents

15 Muret appreciates Tacitus' style, defending it against the accusation of 'obscurity' (cf. e. g. the Oratio XIV 389: Equidem cum istos de obscuritate Taciti querentes audio, cogito, quam libenter homines culpam suam in alios conferant, quantoque facilius omnia alia accusent quam semet ipsos, "When I hear these fellows complaining about the obscurity of Tacitus, I think how readily men transfer their own fault to others, and how much more easily they blame everything but themselves”, translation Scott in Mellor 1995). Furthermore, Tacitus' writings convey a moral-political lesson which offers to Muret the best option to deal with his times, i.e. to be prudent in a time of danger; cf. MacPhail 1990, 147-205.

16 Muret, Oratio XIV 384: Quomodo neque intempestiua libertate utentes uitam suam sine ulla publica utilitate in periculum obiecerint.

17 Cf. Tac. Agr. 43.4; but also see Tac. Ann. 4.20.7; on this parallel, see La Penna 1976, 300 - 301.

18 Claire 2009.

19 The term praelectio in the first century CE means the reading-lesson of the grammaticus before his pupils made their own attempt: cf. Quint. Inst. 1.2.15; 2.5.4; on this point, cf. Bonner 1977, 225.

20 Which will be abbreviated Ingr.

21 M. Antonii Mureti Opera omnia ex mss. aucta \& emendata cum breui annotatione Davidis Ruhnkenii, Leiden 1789, vol. 3, 800-823.

22 Claire 2009, 3-4; on Muret's orationes cf. also Rossi 2006. 
an exceptional document which also offers us an insight into the historical and social framework of Roman academia.

The beginning of the speech is shaped as a sort of prologue in which Muret explains his plan for the class. Muret's first "most felicitous decision" was to propose "to join Plato with Cicero one more time". ${ }^{23}$ Nevertheless, as we read directly after in Muret's speech, he could not pursue this pedagogical programme, as he was told to put Plato aside and to focus only on Cicero. ${ }^{24}$ As Muret explained, his decision to focus on Plato was due to the state of neglect in which Greek literature lay. He claimed to have been the first to propose the study of Plato in Rome, a proposal justified by the importance of that philosopher, capable "of saturating their minds with the bountiful springs of his wisdom and eloquence". ${ }^{25}$ As I will maintain further, Muret considers De officiis the perfect example of how eloquence and philosophy are intrinsically bound to each other; Plato's Republic conveys the same congenital bond.

The interference with his decision and the prohibition of Plato is something with which Muret disagrees, but which does not seriously endanger his obedience and devotion to the institution of the Church. As we read in another inaugural lecture for a course held in 1578 (Interpretaturus C. Sallustium), Muret's intention to carry on teaching Aristoteles' Rhetoric, which he had already taught in 1576, was thwarted by Cardinal Guglielmo Sirleto, ${ }^{26}$ whose activity in Rome and especially at the Vatican Library is described as having been more useful than thirty years of Council in Trento. ${ }^{27}$ As in the case of Sirleto's interference in forbidding a second course on Aristotle, it seems that Sirleto could also be respon-

23 Muret, Ingr. 334: Creueram hoc anno pulcerrimum consilium, quod anno superiore ceperam, persequi, et denuo Platonem cum Cicerone coniungere. Translations are mine unless stated otherwise. Muret's previous course was on the first two books of Plato's Republic.

24 Muret, Ingr. 335: Omnem a me huius anni operam in uno Cicerone consumi maluerunt; on the impossibility of pursuing the original program for this class, Dejob 1881, 274-277; Loverci 2000, 237.

25 Muret, Ingr. 334-335: Tum ut nobilissimus Philosophus, cuius ante me in his scholis nunquam, ut opinor, audita uox erat, paulatim familiarior factus, uberrimis illis sapientiae et eloquentiae suae fontibus ingenia nostra copiosius et abudantius irrigaret.

26 According to Sirleto, quoted by Muret, the students could have felt bogged down by such a difficult topic, and the majority of them could not read nor appreciate the original Greek; furthermore, they might also get bored with a topic they had already encountered. Thus, Sirleto urged Muret to deal with Sallust instead, whose chief merits were his good Latin prose and the strong presence of civic wisdom.

27 This is a letter from Gerolamo Seripando to Sirleto dated 27 August 1562 and conserved in Biblioteca Apostolica Vaticana, Vat. lat. 6189, 119: cf. Zen 2018, 95 for a discussion of the letter. 
sible for forbidding the lessons on Plato and Cicero, obliging Muret to focus on Cicero alone.

\section{De officiis in the sixteenth century: the case of Erasmus}

Behind Muret's decision to focus on Cicero's De officiis for his class, there is a tradition of recognition and appreciation of this work, which transcends the various polemics on Cicero’s imitation.

The debate on 'Ciceronianism', as was already mentioned, concerned the imitation of Cicero's style and vocabulary. Erasmus' Ciceronianus, written in 1528, is an example of such attacks against "la rigida osservanza ciceroniana", ${ }^{28}$ behind which is couched what Erasmus interprets as a new form of paganism. As Bausi made clear, full devotion to literature, aimed at perfecting eloquence and pursuing glory, implies an existence which is distant from human society. Although Erasmus' admiration and praise of Cicero remains authentic, it establishes the subjection of Ciceronian eloquence to the service of Christianity as a prerequisite. The necessity of envisioning a Christian Cicero was already expressed by Petrarch, whose use of Cicero also rests on the firm belief that Cicero could have been a Christian had he lived in other times: Si [sc. Cicero] uidisset Cristum aut nomen eius audiuisset, quantum ego opinor, non modo credidisset in eum sed eloquio illo incomparabili Cristi preco maximus fuisset ("In my opinion, if Cicero had seen Christ, or heard his name, not only would Cicero have believed in him, but, thanks to his unparalleled eloquence, he would have been Christ's greatest champion"). ${ }^{29}$

Although during the Counter-Reformation Ciceronian prose is still a model, there emerges a clearer need to engage with Cicero not only in terms of imitation of his style, but also as a fundamental source for moral contents which are propaedeutic to Christian teachings, rather than incompatible with them. Cicero's De officiis represents the best choice: due to the ethical and political topics it treats, it is fully equipped to satisfy the urgent need for lending moral credibility to a Christian education which cannot do without the rhetorical tools of the classical paideia. De officiis, as we will observe in Muret's speech, will provide the chance to best deal with the complex dialectic between rhetoric and the importance of argumentation.

28 Bausi/Canfora 2016, 42; on Erasmus' Ciceronianus, see also Bausi 1998.

29 Petrarca, Fam. 21.10.13. 


\section{Two letters by Erasmus}

Before dealing with Muret's oration, it is important to return to Erasmus one more time, as Erasmus' reading of De officiis represents a crucial starting point.

Erasmus worked on several editions of De officiis, the first of which was published in 1520. Two letters were inserted in this edition as prefatory texts. In the first letter, written in 1501 to Jacob Tutor (or De Voecht), ${ }^{30}$ De officiis is described through an impressive series of metaphorical images which captures its powerful philosophical nature. Erasmus writes about taking some salutary walks while rereading the three books of De officiis, and feeling unsure of whether he was getting more pleasure or profit out of it. ${ }^{31}$ The books are here called aurei, "golden", an adjective reprised by Muret in Oratio VI to refer to De officiis. ${ }^{32}$ Erasmus, quoting Pliny the Elder, writes that the work should never be out of one's hands. ${ }^{33}$ Because of this recommendation, Erasmus tells us that he "reduced" the bulk of the books, that is to say, he printed an edition with a much smaller font. This result is a handbook (enchiridii uice) which allows one to carry the tome easily and, as Pliny suggested, to learn it by heart. The first meaning of the

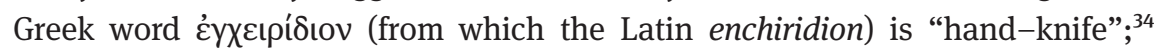
this word, used as a title for Epictetus' work, starts then to convey the meaning of 'manual, handbook', though keeping the semantic nuance of 'something useful to fight with, which fits in the palm of a hand'. In Erasmus' view, De officiis summons all the virtues required from a man educated by classical philosophical paideia, which is both propaedeutic to a good Christian education, and not extraneous to human society. The difficult circumstances in which De officiis

30 This is letter 152, published in Erasmus' first edition of De officiis (1520); the text of Erasmus' Letters cited and referred to in this chapter is that of Allen's 1906-1958 Oxford edition.

31 Erasmus, Ep. 152, 356, 11-15 Allen: In proximis igitur meis inambulationibus [...] tres illos $M$. Tullii De Officiis libellos uere aureos relegimus, incertum maiorene uoluptate an fructu.

32 Muret, Ingr. 335: Peruolutabimus igitur hoc anno aureos illos M. Tullii libros de Officiis.

33 Erasmus, Ep. 152, 356, 16 -19 Allen: Quos quoniam Plinius Secundus negat umquam de manibus deponi oportere, uoluminis magnitudinem quoad licuit contraximus, quo semper in manibus enchiridii uice gestari et, quod scripsit idem, ad uerbum edisci possent; cf. also Erasmus, Conuiuium religiosum, 242 Halkin et al.: Plinius scripsit Officia Ciceronis nunquam de manibus deponenda et sunt sane digna, quae cum ab omnibus tum praecipue $a b$ iis qui destinati sunt administrandae reipublicae ad uerbum ediscantur; the passage of Pliny mentioned by Erasmus is HN praef. 22: qui [sc. Cicero] de re publica Platonis se comitem profitetur, in consolatione filiae "Crantorem", inquit, "sequor," item Panaetium de officiis, quae uolumina ediscenda, non modo in manibus cotidie habenda, nosti.

34 Dealy 2017, 68. 
was written made this powerful pocket book a proper weapon, ${ }^{35}$ as it fought the weapons of those who subverted all moral values. Another meaningful use of the idea of virtues as weapons comes from Cicero's Brutus, in a passage which expresses his worries for the socio-political situation of 46 BCE well. ${ }^{36}$ Here the metaphorical weapons of consilium, ingenium and auctoritas, acquired by Cicero through his education, and necessary for a man devoted to the State as well as for the whole collective, are presented in opposition to the weapons employed by Caesar and his faction. Not by chance, this passage from Brutus continues with a variation of the 'moral weapons', in hendiadys, of auctoritas et oratio. This patrocinium pacis "encapsulates the tight connection between rhetorical capacity and political action", ${ }^{37}$ the main argument of Muret's speech.

The second image sketched by Erasmus comes from the agricultural world; it compares the law studies undertaken by Jacob Tutor, depicted as a rich harvest from the spreading plains, with De officiis, a small field, but sufficient to satisfy all needs, provided it is cultivated with care. In this field it is possible to find the moly, the Homeric herb which works as an antidote to Circe's poisons. ${ }^{38}$

The last image depicting De officiis is that of a spring of divine honesty-the Ciceronian honestum-dividing itself into four streams, which are of course the cardinal virtues. ${ }^{39}$ The peculiarity of this spring, which is making men not only good at speaking (uocalis), but also immortal in terms of morals (immor-

35 Erasmus also depicts De officiis as a pugiunculus, "tiny dagger".

36 Cic. Brut. 7: Equidem angor animo non consili, non ingeni, non auctoritatis armis egere rem publicam, quae didiceram tractare quibusque me adsuefeceram quaeque erant propria cum praestantis in re publica uiri tum bene moratae et bene constitutae ciuitatis. Quod si fuit in re publica tempus ullum, cum extorquere arma posset e manibus iratorum ciuium boni ciuis auctoritas et oratio, tum profecto fuit, cum patrocinium pacis exclusum est aut errore hominum aut timore ("For me too it is a source of deep pain that the state feels no need of those weapons of counsel, of insight, and of authority, which I had learned to handle and to rely upon,--weapons which are the peculiar and proper resource of a leader in the commonwealth and of a civilized and lawabiding state. Indeed if there ever was a time in the history of the state when the authority and eloquence of a good citizen might have wrested arms from the hands of angry partisans, it was exactly then when through blindness or fear the door was abruptly closed upon the cause of peace"), translation Hendrickson in Hendrickson/Hubbell 1939.

37 Fox 2007, 181, who argues that "to be able to use his experience and skill as an advocate for the cause of peace would have been the culmination of Cicero's entire career”.

38 Erasmus, Ep. 152, 357, 38 - 40 Allen: Et quanquam a iurisperitorum latissimis campis opimam frugem demetis, tamen hic agellus licet angustus, si diligenter excolueris, omnia unis suppeditabit; 42-44: Neque alibi reperies Homericam illam herbam quam moly nominat, repertu difficillimam, contra omnia Circes ueneficia praesentissimum antidotum.

39 Ep. 152, 357, 46-48 Allen: Hic fons ille diuinus honestatis in quatuor riuulos se diuidit, qui potus non solum uocalem, ut Aonius ille, uerum etiam immortalem faciat. 
talis), prefigurates the pivotal point in Muret's argumentation: the importance of combining eloquence with moral contents.

In a letter written in $1519,{ }^{40}$ again addressed to Jacob Tutor, Erasmus recounts a trip he took to Brabant and Flanders. The books he decided to bring became travel companions with which to have a pleasant conversation. He lists $D e$ officiis, Laelius, Cato maior and Paradoxa stoicorum, all in small formats, so as not to add weight to his little bag; pocket editions, to all intents and purposes. ${ }^{41}$ The choice of these books, defined a fructus, "a benefit”, offers the opportunity for comparison with recent Christian authors (nostrates quosdam neotericos legens). Cicero's De officiis was capable of motivating him to search for honestum and virtus, while modern Christian authors, although dealing with res magnae and expressing themselves with subtlety, turn out to be cold. ${ }^{42}$ The qualities Erasmus most appreciates in this work are its verisimilitude, its strength, and conformity with nature; nothing is artificial nor idle:

At in praeceptis uiuendi quanta aequitas, quanta sanctimonia, quanta synceritas, quanta ueritas, quam omnia consentanea naturae, quam nihil fucatum aut somnolentium. Quem animum exigit ab his qui gerunt rempublicam! Vt admirabilem illam et amabilem uirtutis spetiem ponit ob oculos! $!^{43}$

What justice, what purity, what sincerity, what truth in his rules for living! -all is in harmony with nature, nothing glossed over or half asleep. What a spirit he demands from those at the head of public affairs! What a notable and lovable picture of virtue he paints before our eyes! ${ }^{44}$

The criticism directed at modern Christian authors applies not only to their skill (or lack thereof) in conveying religious arguments, but also to their morals and their politics. "How we should do good to all men even without being rewarded for it, how to maintain a friendship, the immortality of souls, how to hold unimportant matters in contempt": these are Cicero's moral lessons, reprised by Erasmus and traceable one by one in De officiis, which present-day Christians, clergy-

40 Ep. 1013 Allen.

41 Ep. 1013, 66, 31-33 Allen: Inuitarat autem uoluminis exiguitas, haud multum additura sarcinulae ponderis. Ex huius lectione, mi Tutor, geminum fructum coepi.

42 Ep. 1013, 66, 36-40 Allen: Sic me totum inflammauit ad honesti uirtutisque studium, ut iam pridem nihil tale senserim, nostrates quosdam neotericos legens, qui Christiani Christianae philosophiae mysteria profitentur, et iisdem de rebus magna, ui nobis uidetur, subtilitate disserunt, sed aeque frigide; cf. Vallese 1962, 121.

43 Ep. 1013, 66, 44-48 Allen.

44 Translation Mynors in Bietenholz/Mynors 1987. 
men and monks are unable to learn..$^{45}$ According to Erasmus, Cicero, defined as "a saint, almost a deity", achieved what Christian authors could not. With his De officiis he proposed a concrete political model (talem principem aut magistratum) embodying a philosophical and moral lesson which any contemporary grandee could interpret as ridiculous. ${ }^{46}$

As has been observed, in Erasmus' reception of De officiis it is already possible to find the elements which will then become pivotal for Muret's reading of this work. The representation of De officiis as a moral weapon is particular helpful in understanding why Muret chose this work for his students in his capacity as chair of Eloquence. Eloquence cannot do without moral contents and moral contents strengthen the orator's position when dealing with the political and religious issues posed by the Counter-Reformation. Like Augustine, Erasmus accuses Christian writers of being unable to see what the pagans saw. Despite their lack of Evangelical light (euangelica lux), the pagans were better able to incite to virtue and only due to their natural flare (naturae scintilla). ${ }^{47}$ Thus, Cicero's moral weapon is necessary and propaedeutic to the Christian common good.

\section{Muret's oration}

\section{The last product of Cicero's old age}

After the aforementioned digression on Roman academia, Muret can finally focus on the work he had chosen to teach (transibo ad alia, quae proprie pertinent ad eos libros, quos uobis hoc anno Deo fretus explanare decreui, "I will move on to other matters, which are more strictly related to those books which, trusting in God, I decided to elucidate for you this year"). According to Claire's analysis, this section corresponds to the laus of the work in question. The first justification of his choice (decreui) is offered by none other than Cicero, who is presented as the foremost Roman author with regard to eloquence. In

45 Erasmus, Ep. 1013, 66, 49-52 Allen: De gratis etiam iuuandis omnibus, de tuenda amicicia, de immortalitate animorum, de contemptu earum rerum quarum gratia uulgus hodie, non dicam Christianorum sed theologorum etiam ac monachorum, nihil non et facit et patitur.

46 Erasmus, Ep. 1013, 66, 55-57 Allen: Describe nostris satrapis talem principem aut magistratu qualem describit Cicero, dispeream ni cum sua imagine ut delirus ridebitur.

47 Erasmus, Ep. 1013, 66, 63-68 Allen: Nunquam antehac magis expertus sum uerum esse quod scribit Augustinus, ethnicorum benefactis acriores addi stimulus ad uirtutem quam nostratium, cum subit animo quam turpe sit non id perspicere pectus Euangelica luce illustratum, quod perspectum est iis quibus sola nature scintilla praelucebat. 
fact, his greatness is so undisputed that no one can even be considered 'second' after him. ${ }^{48}$

An additional strong point is Cicero's age when he wrote De officiis, ${ }^{49}$ defined as "almost the last fruit of that remarkable man" (hic prope ultimus illius praestantis ingenii fetus). Cicero's senectus coincides with the most troubled and complex period of the Roman Republic, which is actually its end. Caesar's dictatorship, his death, the second triumvirate and Marc Antony's hostility mark a watershed moment in Cicero's works, a point of no return, which, according to Muret, lends these books added significance. The distinction chiefly consists in the philosophical subjects which, as we will observe, in Muret's view can convey the perfect model of education for students in the Counter-Reformation era. The reason for a composition of De officiis is summarized by Muret with the decision of Cicero, labelled as singularis [...] uir natusque in posteritatis exemplum, to "procure for himself a strength of both wisdom and prudence" (immensam sibi quandam uim sapientiae ac prudentiae comparasset). The creation of such a powerful handbook, whose greatest fighting strength is wisdom, as Erasmus would say, is only possible thanks to Cicero's ability to work in such a hostile political environment. For Muret, the merits of De officiis are to be attributed to Cicero's commitment, the nightly vigils dedicated to its composition, and his expertise and treatment of the manifold questions relating to politics and human affairs. However, it is exactly the historical contingency of the ultimate fate of the Republic and the enforced otium to which Cicero is bound which made De officiis such an important work for the exhortation to wisdom. The expression employed by Muret to describe the difficulties of Cicero during the time of writing De officiis is multi casus, "many failings". To cite Cicero's own words describing the feelings tied to the multi casus, "I am kept by force of armed treason away from practical politics and from my practice at the bar, I am now leading a life of leisure. For that reason I have left the city and, wandering in the country from place to place, I am often alone" (Off. 3.1)..$^{50}$

48 Muret, Ingr. 336: Primum quod Ciceronis sunt, hoc est, eius uiri, qui perpetuo omnium aetatum consensu inter Romanos scriptores eloquentiae laude ita numeratur primus, ut ab eo nemo numeratur secundus.

49 Muret, Ingr. 336: Deinde quod scripti a Cicerone iam sene. See Pieper in this volume for a discussion of Renaissance commentators reading the Philippics as Cicero's Spätwerk (pp. 181-185). 50 Cic. Off. 3.1: Nam et a re publica forensibusque negotiis armis impiis uique prohibiti otium persequimur et ob eam causam urbe relicta rura peragrantes saepe soli sumus; translation Miller 1913. It is interesting to notice how Muret does not mention that De officiis was written at the same time as the first two Philippics, which shed further light on the hostile environment around Cicero. 


\section{A fruit of which Cicero is (rightly) proud}

Another point submitted to the students is the self-consciousness which marks this work and involves its addressee: Cicero's son Marcus, who was in Athens to complete his education under the guide of the philosopher Cratippus (Off. 1.1). Some critics have indeed stressed the importance of Cicero's choice to address this book to his son, and interpreted the literary form of De officiis in light of its chosen addressee. ${ }^{51}$ Marcus embodies the younger generation which is being educated in dramatic political circumstances, and this concern could have contributed to the peremptory tone of the treatise. It is not hard to see why Muret chose this book to instruct students at the difficult time of the Counter-Reformation.

But it is also interesting to notice how Muret links Cicero's aim of educating both his son and his son's entire generation with Cicero's own awareness of having produced a great work. For Muret, the "good and useful teachings" (bona et utilia praecepta) were collected by Cicero with the aim of giving a foundational law and rules for life (lex ac norma instituendae uitae), an expression which is reminiscent of the formula honestae uitae ("the rule for an honest life") from Seneca's lost De officiis. ${ }^{52}$ However, according to Muret, sending this work to Athens, the "temple of erudition", would have offered Cicero the chance to submit it also to the judgment of the philosophers who surrounded his son. This, Muret argues, could be the main reason behind the refined, polished style of the work, ${ }^{53}$ a curious opinion which is quite divergent from the consensus among modern scholars. According to the latter, ${ }^{54}$ both the speed of the composition and the difficult working conditions have left traces, such as the absence of Cicero's usual long, hypotactic periods, or the presence of overlaps and repetitions of the same concepts. Nevertheless, Muret insists on the stylistic perfection of this work, a perfection of which Cicero too must have been well aware. ${ }^{55}$ Furthermore, Muret calls attention to how Cicero defines De officiis as "a gift" (munus)

51 On the excessive attention given to Cicero's son Marcus, cf. Fedeli 1973, 358 and footnotes. 52 This is the title of a work by Martin of Braga, which might be inspired by Seneca's lost $D e$ officiis (fr. 57 Vottero).

53 Muret, Ingr. 337: Neque quidquam praetermissum in limandis ac perpoliendis, quae scriberentur, ut in eam urbem, quae tum eruditionis ac sapientiae domicilium erat, acutissimorum hominum subitura iudicium ("Nor was anything neglected in the process of polishing and refining what was being written, insofar as it was meant to be submitted to the judgment of the exceedingly sharp men from the city which at the time was home to all erudition and wisdom").

54 Narducci 2007, 6-7.

55 Muret, Ingr. 337: Constat etiam ipsum sibi ualde placuisse in confectione horum librorum, ut qui sibi unus optime conscius esset operae in eis scribendis collocatae. 
for his son at the end of the book, while at the beginning he had recommended it to improve his command of the Latin language. As a proof of Cicero's self-awareness of the value of De officiis, Muret quotes a letter to Atticus. ${ }^{56}$ According to Muret, ${ }^{57}$ Cicero's words of praise for his own work in this letter (magnifice explicamus) are revealingly self-confident. In fact, these words would mean that Cicero does not fear the judgment of Atticus, who is presented in the letters as a severe judge whose corrections in red pencil are to be feared..$^{58}$ The famous passage from the Atticus-letter gives us a concise and effective summa of De officiis and it agrees with Muret's portrayal of this work: namely, it emphasizes the crucial role played by philosophy in connection with Cicero's duty towards his son Marcus. Furthermore, Cicero's mention of the peregrinatio in his letter sets his self-imposed exile after Caesar's death as the backdrop for the composition of De officiis. Since this oratio is intended as a speech to his students, Muret takes care to anticipate possible objections to Cicero's pride in his own work, which would make him no better than an Astydamas. ${ }^{59}$ Muret's preventive defence also concerns the praise of the book by wise people from all ages, who recommended to learn De officiis by heart (ad uerbum ediscerentur). This statement confirms De officiis' role as a manual, a handbook to study and consult in matters of moral and socio-political behaviour; an evaluation of the book which is consistent with Cicero's proposal. A particularly interesting individual among the sample of wise people chosen by Muret is Alexander Severus, an emperor traditionally known as a good one. According to the biography ascribed to Lampridius in the Historia Augusta (Alex. 30.2) Alexander was deeply devoted to both Greek and Latin literature, and his readings (Plato's Republic, Cicero's De re pu-

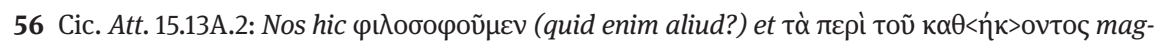

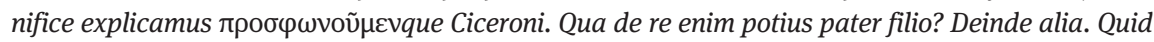
quaeris? Exstabit opera peregrinationis huius.

57 Muret, Ingr. 337: Et ad Atticum scribens homini eruditissimo et cuius ipse saepe miniatulas ceras extimescebat (referring to Att.15.14.4 and 16.11.1) magnam huius operis exspectationem concitare non ueretur; Muret does not say anything about a possible reaction by Atticus.

58 In a previous letter (Att. 15.14.4), Cicero expressed worry about Atticus' reading of the phil-

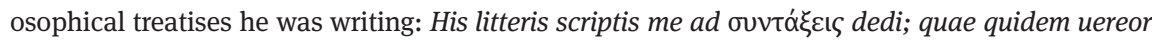
ne miniata cerula tua pluribus locis notandae sint (the ouvtáłદı,,"treatises”, mentioned could allude to De officiis, but also other works have been suggested, such as De gloria and De amicitia). Apparently, moving forward in De officiis' composition, Cicero became more self-confident as regards the value of his treatise.

59 Muret, Ingr. 337: Ac ne quis ipsius, quasi Astydamantis cuiusdam, de se testimonium eleuare conetur, sciat hos libros semper fuisse in prima commendatione apud sapientissimos quosque, ut et tererentur assidue manibus, et a plerisque etiam ad uerbum ediscerentur; Astydamas was a

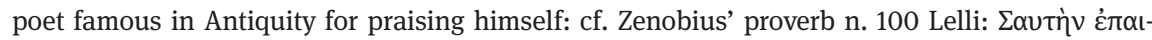

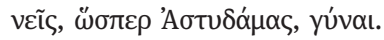


blica and De officiis) created a path which Muret is proud to follow (sapientissimi imperatoris uestigia persequamur).

\section{Moral contents}

The main point of Muret's speech is his decision to focus on De officiis on the basis of the excellence of the moral contents found in it: Nihil est, quod magis inuitare atque allicere nos debeat ad accuratam horum librorum lectionem, quam res ipsae, de quibus in eis disputatur ("There is nothing that invites and prompts us to read these books carefully more than the very topics discussed therein").

The summary that follows offers an exhaustive description of the political and moral teachings developed by Cicero. "How each person should act in every part of life" (Quomodo unusquisque in omni parte uitae gerere se debeat) encompasses the authoritative tone and the prescriptive nature of the treatise, first of all focused on the right moral behaviour of each person. "What is demanded of each person" (Quid a quoque postuletur) shifts the focus onto the main argument of the treatise, the duties, and points out the socio-political perspective, as this part focuses on what the state wants from citizens. "What is proper for each person" (Quid quemque deceat) clearly refers to decorum, a crucial topic of the treatise. Decorum concerns the fourth part of the honestum, from which it is never separated. ${ }^{60}$ The phrase quid patriae praestandum sit, quid parentibus, quid propinquis ceterisque amicis, quid uniuerso hominum generi ("what duties must be fulfilled towards the fatherland, towards one's parents, relatives, close friends, and the entire human race") recalls the explication given by Cicero of the degrees of human society and of duties towards these degrees. ${ }^{61}$ As we read in De officiis, the order of obligations puts the fatherland first -the patria mentioned by Muret-followed by parents, children and acquaintances. Muret respects this hierarchy, emphasizing from where all the degrees have their origins: the whole of mankind. ${ }^{62}$ In order to insist on the moral strength of these teachings Muret inserts two verses from a letter by Horace. ${ }^{63}$ This allows him

60 The focus on decorum concerns Off. 1.93-151.

61 Cf. Cic. Off. 1.53-60.

62 Cf. Cic. Off. 1.53: Ab illa enim inmensa societate humani generis in exiguum angustumque concluditur. The focus on the whole of mankind recalls the Stoic conception of cosmopolitanism, cf. Schofield 1999 for an in-depth analysis.

63 Muret, Ingr. 337: Ea denique, quorum studium "Aeque pauperibus prodest, locupletibus aeque; | aeque neglectum pueris senibusque nocebit”; verses from Hor. Epist. 1.1.25-26. 
to explain how the moral of De officiis will be useful to both the poor and the rich.

Two more points are added by Muret to the general description of moral contents in De officiis. The first is a reference to Socrates, who stresses the importance of focusing on moral philosophy rather than on other branches of the same topic. ${ }^{64}$ The second is a positive judgment on Cicero's ability to adapt Stoic philosophy, considered too rigorous and beyond the grasp of common citizens, to his educational project, which is devoted to offering practical teachings on socio-political behaviour. Muret's definition of Stoicism as a seuerum et masculum philosophandi genus, "an austere and masculine kind of philosophy”, emphasizes the masculinity traditionally assigned to Zeno's philosophy, stressed by different authors including Seneca, concerning rigida ac uirilis sapientia, "unyielding manly wisdom" ${ }^{65}$ Muret draws on the same Ciceronian criticisms of Stoicism that we read in the fourth book of De finibus, ${ }^{66}$ where Cicero rejects the excessive obscurity of philosophical concepts and the abstruseness of the language. ${ }^{67}$ Moreover, Muret asserts that the identification of the supreme good with virtue ${ }^{68}$ to the exclusion of everything else makes the correct organization of one's own existence impossible, since every possible course of action is already predetermined. Stoicism's excessive intellectualism, as Muret remarks, makes Stoic teachings remote and impossible to actualize. Cicero's great merit has been to soften this excessively strict philosophy for the purpose of arranging civil life: Ita se Cicero temperauit, ut ab illis, quae absurda aut erant aut uideri poterant, abstinuerit omniaque ad ciuilis uitae institutionem apta et accommodata protulerit ("Cicero was so self-disciplined as to abstain from what either was fool-

64 Muret, Ingr. 337-338: Socrates quidem, qui in his et talibus quaerendis studium omne consumerent, eos sapere unos praedicabat: qui, his neglectis de natura mundi, de rebus superis, de caussis uentorum, imbrium, fulgurum philosopharentur, desipere hallucinarique dicebat.

65 Sen. Helu. 12.4; cf. Diog. Laert. 7.30: "Thou madest self-sufficiency thy rule, Eschewing haughty wealth, $\mathrm{O}$ godlike Zeno, With aspect grave and hoary brow serene. A manly doctrine thine," translation Hicks 1925; Lucian, Bis. acc. 20: "I see that most of you [...] contemptuous of me because my head is close-clipped, my glance is masculine, and I seem dour”, translation Harmon 1921.

66 On the criticism of Stoic ethics, cf. Ioppolo 2016.

67 Cf. e.g. Cic. Fin. 4.2: Non mehercule, inquam, soleo temere contra Stoicos, non quo illis admodum assentiar, sed pudore impedior; ita multa dicunt, quae uix intellegam.

68 Cic. Fin. 4.68-77: cf. e.g. 4.68: Cum enim, quod honestum sit, id solum bonum esse confirmatur, tollitur cura ualitudinis, diligente rei familiaris, administratio rei publicae, ordo gerendorum negotiorum, officia uitae, ipsum denique illud honestum, in quo uno uultis esse omnia, deserendum est. 
ish or could be perceived as such, and brought forward everything that was appropriate and fit for an education to civic life”, Ingr. 238).

\section{Eloquence and philosophy}

This last section focuses on the concluding part of Muret's speech, which is also the climax of his argument. After the laus of the proposed work, the last part of the speech should be devoted to the cohortatio, the exhortation to study the author in question. ${ }^{69}$ In the case of the Oratio VI, the exhortation coincides with a fierce new apology by Muret, this time towards people who criticize him for being inconsistent. The incoherence would consist in focusing on a work which is not strictly on the subject of rhetoric when teaching the subject of eloquence. $^{70}$ Thus, the section resembles a proper forensic peroratio, in which Muret presents all the arguments to defend his cause.

The core of Muret's self-defence concerns Cicero's crucial treatment of the relation between wisdom and eloquence. In De inuentione Cicero had already begun to sketch out the fundamental idea that eloquence cannot be conceived without wisdom. ${ }^{71}$ The synthesis between eloquence and wisdom is here already oriented in a socio-political direction, which will be taken up again in De oratore and then finally in De officiis. As Narducci points out, De oratore aims to "azzerare il pernicioso divario tra una retorica di basso profilo e sprovvista di sapientia etico-politica e una filosofia che ha in genere reciso il diretto legame con la vita pubblica". ${ }^{72}$ The model of the orator proposed in De oratore already aimed to educate and instruct human society, as we read through Crassus' words:

Vt uero iam ad illa summa ueniamus, quae uis alia potuit aut dispersos homines unum in locum congregare aut a fera agrestique uita ad hunc humanum cultum ciuilemque deducere aut iam constitutis ciuitatibus leges iudicia iura describere? [...] Comprehendam

69 See the analysis by Claire 2009.

70 Muret, Ingr. 338: Aiunt enim, perperam facere me, qui cum iussus sim, quantum quidem uires meae ferunt, eloquentiae praecepta tradere, eiusmodi tamen fere libros interpreter, qui non tam bene dicendi quam bene uiuendi praecepta continere uideantur.

71 Cic. Inu. rhet. 1.1: Ac me quidem diu cogitantem ratio ipsa in hanc potissimum sententiam ducit, ut existimem sapientiam sine eloquentia parum prodesse ciuitatibus, eloquentiam uero sine sapientia nimium obesse plerumque, prodesse numquam ("For my own part, after long thought, I have been led by reason itself to hold this opinion first and foremost, that wisdom without eloquence does too little for the good of states, but that eloquence without wisdom is generally highly disadvantageous and is never helpful", translation Hubbell 1949).

72 Narducci 1997, 67. 
breui: sic enim statuo, perfecti oratoris moderatione et sapientia non solum ipsius dignitatem, sed et priuatorum plurimorum et uniuersae rei publicae salutem maxime contineri. ${ }^{73}$

To come, however, at length to the highest achievements of eloquence, what other power could have been strong enough either to gather scattered humanity into one place, or to lead it out of its brutish existence in the wilderness up to our present condition of civilization as men and as citizens, or, after the establishment of social communities, to give shape to laws, tribunals, and civic rights? [...] I will conclude the whole matter in a few words, for my assertion is this: that the wise control of the complete orator is that which chiefly upholds not only his own dignity, but the safety of countless individuals and of the entire State.

The third book of De oratore also deals with the relationship between eloquence and philosophy, offering a series of historical precedents, beginning with Phoenix, Achilles's teacher, chosen by his father Peleus for the purpose of making his son into an orator and a man of action at the same time. ${ }^{74}$ It is not by chance that Muret also starts his argumentation with the importance of combining the two disciplines from the heroic age, offering the example of Homer's Phoenix. ${ }^{75}$ Probably inspired by this passage from De oratore, Muret quotes Homer's verses from the Iliad directly, whereas Cicero translates them. Muret affirms then the necessity of providing the good orator with knowledge of moral philosophy, even if this purpose is reachable in two different ways.

The first is the model of the eloquent man described by Cato the Censor, the uir bonus dicendi peritus, who is able to teach "the best part of philosophy". ${ }^{76} \mathrm{Ci}$ cero's De oratore presents the figure of Cato as an incarnation of the perfect ora-

73 Cic. De or. 1.33-34. Translation Sutton/Rackham 1942.

74 Cic. De or. 3.57: Nam uetus quidem illa doctrina eadem uidetur et recte faciendi et bene dicendi magistra; neque disiuncti doctores, sed eidem erant uiuendi praeceptores atque dicendi, ut ille apud Homerum Phoenix, qui se a Peleo patre Achilli iuneni comitem esse datum dicit ad bellum, ut efficeret oratorem uerborum actoremque rerum ("For in old days at all events the same system of instruction seems to have imparted education both in right conduct and in good speech; nor were the professors in two separate groups, but the same masters gave instruction both in ethics and in rhetoric, for instance the great Phoenix in Homer, who says that he was assigned to the young Achilles by his father Peleus to accompany him to the wars in order to make him 'an orator and man of action too", translation Sutton/Rackham 1942).

75 Muret, Ingr. 338: Sed ne quis sit error, hoc sibi responsum habeant iam inde ab heroicis temporibus coniunctam fuisse harum rerum professionem, idque uel illo cognosci Homeri loco, ubi

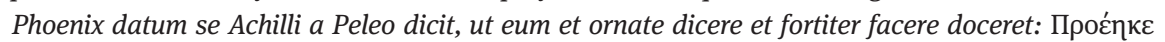

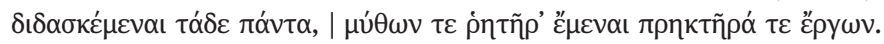

76 Muret, Ingr. 339: Et certe, siue uera est M. Catonis illius sapientis definitio, oratorem esse uirum bonum dicendi peritum: qui quomodo uir bonus fias, docet, potiorem ac praestantiorem partem artis oratoriae docet; siue Aristotelem sequi malumus, ut quamlibet bonum oratorem esse posse dicamus, etiam qui non sit uir bonus. 
tor, because he has knowledge concerning different disciplines. ${ }^{77}$ But besides all this, Cato, holding office, is also a man of the State-this is the real meaning of the adjective bonus implied by Cato and accepted by Muret as well. Eloquence, from a Ciceronian perspective, is what allows the coordination of all disciplines from a socio-political perspective.

According to Muret, the second route to becoming a good orator is that shown by Aristotle, who in the Rhetorica ${ }^{78}$ explains how being a good orator does not presuppose being a good man. In another speech, Muret presents the same sequence of Cato's portrayal of the perfect orator and then of Aristotle's concept that the art of rhetoric does not necessarily imply being a good man. ${ }^{79}$ In this context, Muret calls this art distinguished, "which teaches that part of injustice through which nothing is worse than the fact you can deceive a lot while you look like an honest man," echoing De officiis 1.13. ${ }^{80}$ Nevertheless, according to Muret, neither of these two ways will be useful to the eloquent man without the knowledge of moral philosophy: Facere tamen nullo modo possumus, quin eam partem Philosophiae, qua formantur mores, oratori futuro necessariam esse fateamur ("However, absolutely nothing can be accomplished if we do not admit that the branch of philosophy which shapes one's moral customs is essential for an orator to-be"). As regards the Aristotelian path, moral philosophy becomes particularly necessary because a good orator who is not also a good man needs to make up for his lack of ethics.

Moral philosophy is sophistically presented by Muret as a fundamental requirement for any activities concerning oratory. ${ }^{81}$ According to this argument,

77 Cic. De or. 3.135.

78 Arist. Rhet. 1.2, 1356a ff.

79 Muret, Cum in Platone explicando progrederetur [henceforth Cum in Platone] 330: Hoc uiri boni erat, non oratoris boni. Immo uero, ait alius, ne orator quidem esse potest, nisi qui uir bonus sit. Scio istud dici et ad auctorem M. Catonem referri: sed me magis Aristoteles mouet, qui me Philosophus cum aliis rebus rapit, tum quod mirifice ueritatis amans uidetur. Is igitur, bonus uir sit orator an minus, negat quicquam ad artem pertinere: illud quidem esse in arte uel praecipuum, ita fingere ac conformare orationem, ut te, quicunque sis, ii qui audient bonum uirum esse et sibi amicum putent.

80 Muret, Cum in Platone 330: Egregiam uero et expetendam artem, quae eam iniustitiae partem doceat, qua nulla capitalior est quo modo consequi possis, ut cum maxime fallas, tum maxime uir bonus esse uidearis.

81 Muret, Cum in Platone 339: Quomodo enim apte et copiose aut laudabit aut uituperabit, nisi qui uirtutum uitiorumque naturam, ex quibus omnis uera laus et omnis uituperatio nascitur, diligenter cognitam ac pertractatam habuerit? Quomodo potens et efficax in suadendo aut dissuadendo futurus est, qui, quae secundo horum librorum de utili atque inutili traduntur, nunquam didicerit? Quid aget in iudiciis, qui iustitiae iniustitiaeque cognitionem e Philosophorum fontibus haurire neglexerit? 
the knowledge of the nature of vices and virtues, i.e. the traditional subject of moral philosophy, is essential for praising and vituperating. The comprehension of what is useful or not, described in the second book of De officiis, is essential for the art of persuasion or dissuasion. In the same way, it would be impossible to win a trial if an orator had not learnt from philosophers the concepts of justice and injustice.

This insistence on moral philosophy in order to defend the choice of De officiis for his course on eloquence makes it clear how Muret views this subject in a Ciceronian way. That is, on the one hand he interprets eloquence as a philosophy of language and education, a propaedeutic instruction for being a good citizen within a socio-political community; on the other, he interprets philosophy as the art of guiding people towards the honestum. ${ }^{82}$ Crucially, Cicero himself exhorts his son Marcus to place De officiis-representing here one of his philosophical books-beside his forensic orations: the incitement is to read both orations and philosophical books carefully, ${ }^{83}$ which would mean considering these apparently different kinds of books as different elements of the same thing. Eloquence is not the abstract and artificial subject developed by the pedantic followers of Cicero's style, the Ciceroniani. Eloquence is to be interpreted as a wider subject which comprises philosophy, law, dialectic and which allows one to become a better person, and, above all, a person integrated in human society.

A link with Plato's Republic is hopefully beginning to emerge. Plato approves of eloquence only when it is used by philosophers, who are capable of exploiting it for the common good of humanity. When eloquence is joined with philosophy and conveys the truth, it becomes an educational tool for citizens. In the oration on Plato's Republic already mentioned above, Muret clearly argued that eloquence can otherwise be used in the wrong way. Nevertheless, Muret stresses that "its [eloquence's] purpose is to serve innocence, not crime, to serve justice, not injustice, to serve the truth, not falsehood". ${ }^{84}$ As McGinness states, "Plato's Republic provides the best answer to the question of eloquence and virtue, for it notes that the cultivation of eloquence had as its aim the extirpation of criminal

82 Alfonsi 1975, 114.

83 Cic. Off. 1.3: Quam ob rem magnopere te hortor, mi Cicero, ut non solum orationes meas, sed hos etiam de philosophia libros, qui iam illis fere se aequarunt, studiose legas-uis enim maior in illis dicendi sed hoc quoque colendum est aequabile et temperatum orationis genus.

84 Muret, Cum in Platone 329: Nam quod a multis persaepe dictum est, non eloquentiae istam culpam esse, sed hominum ea secus, quam oportet, utentium; ipsius quidem hunc esse finem, ut innocentiae, non flagitio, ut aequitati, non iniustitiae, ut ueritati, non ut mendacio patrocinetur: uideamus, ne rebus ipsis haec oratio refellatur. 
contagion, not its promotion". ${ }^{85}$ This idea of eloquence pursued by evil individuals is also stressed by the tradition of the Jesuits and of the Collegio Romano, whose links and relationship of reciprocal influence with Muret have been thoroughly elucidated. ${ }^{86}$ It is enough to quote the example of Perpiña, who theorizes the importance of eloquence as a weapon to fight against the heretics, "impious and perfidious" people who made depraved use of the same arms. ${ }^{87}$

As has been pointed out, in De officiis, unlike in De inuentione, "neither orators nor eloquence are invoked as the institutors of Society". ${ }^{8}$ In De officiis, moral philosophy's essential message on 'what is right for a man to do' is an adequate lesson for younger generations. This, however, does not imply an abandonment of eloquence. On the contrary, it implies the subsuming of eloquence as a coordinating force for all disciplines: in fact, eloquence coincides with $s a$ pientia. If in the Orator wisdom was the fundamentum of eloquence, as of other things, ${ }^{89}$ in De officiis this distinction becomes superfluous: the praise of sapientia found in the first book ${ }^{90}$ is enough to explain this new perspective where wisdom, and consequently eloquence, is subsumed into the socio-political purpose of educating mankind. In Raylor's words, "in this account, the key factor is the existence, among human beings, 'of fellowships and society' (communitatis et societatis humanae) and the founding principle of such society is the existence of a connection 'which can be perceive in the universal society of the human race (quod cernitur in universi generis humani societate)'". ${ }^{91}$ The passage from De officiis quoted by Raylor ${ }^{92}$ goes on to say that two crucial elements unite human beings in a universal family: ratio and oratio. The expression ratio et ora-

85 McGinness 1995a, 24.

86 Cf. e.g. Fumaroli 1980, 162-169 and McGinness 1995b. Muret exerted considerable influence on the academic and literary trends among the Collegio Romano. Francesco Benci, a distinguished Jesuit, was a student and friend of Muret's, who left all his books to the Collegio after his death. The Collegio spread Muret's works in Europe and printed his unpublished manuscripts.

87 Perpiña, De arte rhetorica, 149-150; cf. McGinness 1995a, 15.

88 Raylor 2018, 19.

89 Cic. Orat. 70: Sed est eloquentiae sicut reliquarum rerum fundamentum sapientia.

90 Cic. Off. 1.18-21.

91 Raylor 2018, 19; for De officiis' purpose to indicate "quale deve essere il rapporto che il cittadino politicamente impegnato ha verso lo stato, cioè verso la comunità sociale di cui è parte”, see Gabba 1979, 124.

92 Cic. Off. 1.50: Optime autem societas hominum coniunctioque seruabitur, si, ut quisque erit coniunctissimus, ita in eum benignitatis plurimum conferetur. Sed quae naturae principia sint communitatis et societatis humanae, repetendum uidetur altius. Est enim primum quod cernitur in uniuersi generis humani societate. 
tio, aiming to translate the Greek word logos, ${ }^{93}$ embodies what makes humans different from animals, what prompts them to treat each other as social beings, and constitute a community. If there is no emphasis on eloquence, the speech as a founding part of human beings together with reason shows the direction followed by this work and its scope in instructing young people to the honestum through their human and intellectual skills. Post-tridentine preachers will call attention to ratio and oratio as representing signs differentiating humans from beasts, ${ }^{94}$ as well as the Christian harmonization between res and uerba. ${ }^{95}$ As regards civil commitment, the orator's duties towards the respublica christiana, Perpiña, alongside Silvio Antoniano, represents one of the most meaningful voices of the Jesuit tradition. ${ }^{96}$

\section{Muret's final remarks}

The last section of Muret's speech on De officiis concludes with a renewed assertion of the pedagogical value of combining Plato's Republic with Cicero's philosophical work. ${ }^{97}$ After affirming the importance of combining uerba and res, ${ }^{98}$ three verses of Horace's Ars poetica (309-311) summon first the ideal of wisdom as a foundation of eloquence (scribendi recte sapere est et principium et fons, "of good writing the source and fount is wisdom"), then the importance of philosophy in the writings of Socrates' followers (rem tibi Socraticae poterunt ostendere chartae, "your matter the Socratic pages can set forth") and finally the principle of the subject driving the words (uerbaque prouisam rem non inuita sequentur, "and when matter is in hand words will not be loath to follow"). ${ }^{99}$ Once the right training for such philosophical eloquence is clarified one last time,

93 Cf. Dyck 1996, 167-168.

94 McGinness 1995a, 21.

95 The harmonization of res and uerba finds the perfect realization in "Christ, the Logos, the Wisdom of God, who in his incarnate nature spoke the divine arcana in human speech", as stated by McGinness 1995a, 21.

96 McGinness 1995a, 14; 20.

97 Muret, Ingr. 339: An ego si troporum ac schematum exempla traderem [...] plus uobis ad eloquentiam prodessem, quam cum aut libros Platonis de republica aut Ciceronis philosophica interpretor?

98 Muret, Ingr. 339: Vera et solida eloquentia non tantum in uerbis posita est, sed in rebus; in this statement, Muret is invoking Seneca: cf. Ep. 20.2, uerba rebus proba; Ep. 83.7, deformitatem rei et inportunitatem ostende rebus, non uerbis.

99 This is a variation of the Catonian rem tene, uerba sequentur; translation Rushton Fairclough 1926. 
Muret can formulate its antithesis, which is inanis loquacitas, "empty loquacity". A possible pitfall (atque hoc deterius eunt res) is the pedantic attention to words, which actually reveals a negligence in the use of those very same words. In reporting this attitude, considered childish and excessively zealous, Muret is thinking of the Ciceroniani, especially people like Nizzoli. ${ }^{100}$ Once again, on the one hand, pedantic imitation of Cicero is stigmatized; on the other, Cicero's true lesson is learned: the model behind the words bona ac lecta suggested by Muret is Cicero, who recommends using "chosen words" in Brutus and in the Orator. ${ }^{101}$ Fumaroli has clarified how Muret, drawing from both Erasmus and the directives from the Council of Trent, submitted elocutio to "learned inuentio, nourished by Seneca and the Fathers"; nevertheless, he never gave up using the elegantia Ciceroniana, ${ }^{102}$ considered a crucial element for powerful speech by the wise orator.

Muret deals with the topic of eloquence also in the speech, already mentioned above, ${ }^{103}$ for his inaugural lecture as Chair of Eloquence in 1572. On the one hand, this oratio is a strong critique of the Ciceroniani; ${ }^{104}$ on the other, the oratio focuses on the true meaning of eloquence, which is to serve both political and civic activities and, consequently, in accordance with the environment of Roman Counter-Reformation, the Catholic Clergy. This speech offers one more illuminating perspective on its historical context. First, inspired by Pseudo-Longinus' On the Sublime, ${ }^{105}$ Muret treats the skill of moving the audience and of inciting its admiration. For Muret, however, the eloquent man's enthousiasmos sparks the necessity to talk about ciuilia negotia, "public affairs". ${ }^{106}$ What is required of the eloquent man is an education which spans every field of knowl-

100 Cf. above (p. 198).

101 Cic. Brut. 250; Orat. 170; 227.

102 Cf. Fumaroli 1983, 259: "The values required by Cicero for the latter [sc. elocutio], latinitas, urbanitas, elegantia, the art of flattering the ear by the harmonious music of the style, are, for him, not incompatible with the Christian and philosophic erudition of the wise man. On the contrary, it is through this Ciceronian music that the wise man at court will succeed in having his wisdom listened to and in having it enter into the exercise of power”, see also Fumaroli 1980, 171-172 and passim.

103 Cf. above (p. 198).

104 This speech has been interpreted as the most impressive document of Muret's supposed anti-Ciceronianism: cf. Croll 1966.

105 Fumaroli 1980, 165-168 shows how Longinus influenced the rhetorical theories of the late sixteenth century.

106 Muret, De uia et ratione 262: Aliud antiqui uocabant eloquentiam: qui nisi qui de ciuilibus negotiis ornate ac copiose loqui posset, qui dicendo animos audientium flecteret, qui admirationem concitaret, qui modo clamores faceret, modo circumfusam multitudinem stupore defigeret, neminem eloquentem uocabant. 
edge, consisting of dialectic (multa de ratione argumentandi, "several matters concerning the criteria for argumentation"), moral philosophy (multa de uirtutibus ac uitiis, multa de permotionibus animi, "several matters on virtues and vices, and several more on emotions"), history and law (multa de ueterum institutis ac legibus, multa de ratione instituendarum ac gubernandarum, "several matters on the institutions and laws of the ancients, many more on the criteria for education and government"). Thus, a definition of eloquence which only covers the technical skills of persuasion is excluded-and persuasion, as was already observed, opens eloquence up to evil aims as well. Rhetor or sophista are indeed terms to be rejected; instead, Muret proposes the meaningful name of politicus.

\section{Conclusion}

To summarize, Muret aims to turn his students of the University in Rome into politici and enable them to "know how to do and say the right things to get ahead in politically perilous times". ${ }^{107}$ As MacPhail points out, the Counter-Reformation is a complex time in terms of conflicting political forces, but most of all in terms of the necessity of a spiritual renewal which would start from Christian-ethical contents. Educating a new class of people in eloquence was interpreted by Muret first as getting rid of the sterile imitation of Cicero's style, which, as has been noticed, was widespread among both clerical and lay people in the Council of Trent. ${ }^{108}$ Once free of the shadow of a degraded and pedantic reproduction of Cicero which opens up accusations of continuing fondness for paganism, Muret can focus on what he believes to be truly necessary to becoming an orator. Passing through Aristotle and Plato, he reinforces his idea of an eloquence strictly connected with politics and ethical issues. Cicero's De officiis was the best option: not a work on eloquence, but a philosophical treatise written by Cicero in the most difficult period of his life. The innovation of the work, reflecting Cicero's personal situation, is a focus on civic-political commitment which also allows for different life choices. The most important thing is not yielding to selfishness nor forgetting one's duties towards the community. In Muret's view, a good student in eloquence can choose whatever life he desires as long as he cultivates his cultural background and keeps focusing on his duties as a citizen with the purpose of being a good Christian, dicendi peritus. Muret himself will eventually

107 MacPhail 1990, 150.

108 Gatti 2017. 
become dissatisfied with his life split between civil commitments and teaching. Total adhesion to his Christian mission will see him become a priest in 1580 .

As has been observed, the relation between the uita actiua and the uita contemplatiua was a fundamental topic in the post-tridentine Church, where the preacher was considered a uir eloquens, that is a "bishop whose skill in preaching came not just from a theological education but from the kind of broad background recommended by Cicero and Quintilian". ${ }^{109}$ If the sacred orator consequently embodies 'the contemplative in action', we can say that Muret has learnt the lesson of Cicero's De officiis. In this work, due to Cicero's 'forced otium' in such a difficult political situation, the relation between contemplative and active life shifts back towards the traditional suspicion of a leisure devoted only to studies and meditation. ${ }^{110}$ Muret gets the title of ciuis Romanus: becoming a priest meant neither sacrificing attention to political and civil commitments nor being devoted to Cicero's style. Such behaviour certainly conforms to the spirit of De officiis. 
